\title{
An Analysis of Essentialism and Anti-essentialism in Literature
}

\author{
Yanqing Zheng \\ School of Liberal Arts \\ Northwest University for Nationalities \\ Lanzhou, China
}

\begin{abstract}
Today, more and more experts and scholars think that the concept essentialism and anti-essentialism are very complex and difficult to understand. In the second half of the 20th century, anti-essentialist post-modernism arose. And the impact of its cultural studies there still can't be ignored today. Contemporary western scholars take a non-essentialist, historical and inclusive attitude on literature and the nature of literature. And they emphasize the specific socio-cultural context of the various definitions of literary nature rather than seek its universality. Therefore, in view of the present situation, this article through the analysis of domestic and foreign experts and scholars of essentialism and anti-essentialism research overview, sorted out, summed up the relevant literature.
\end{abstract} impact

Keywords-essentialism; anti-essentialism; today's society;

\section{INTRODUCTION}

For a long time, people's understanding and usage of the concept of essence are mainly influenced by Aristotle's point of view. The term essence was first invented by Aristotle and appeared in his book Metaphysics. The concept about essence is substantially regarded as the concept that created, in Aristotle's words, the definition of the essence is "species of genus". The essence of literature has become the core problem of literary research, which means that literature seems to have an eternal character. This is influenced by Aristotle's practical ontological concept. Actually, the concept of essence comes from classical western ontology pioneered by Plato. This doctrine is a kind of special exploration and solution to the problem of existence. It transforms the rich existence problem into the abstract constant essence question. The concept of essence is usually relative to "phenomenon" and belongs to the category of cognitive area.Eagleton believes that the nature of literature is not like an object which exists in a place objectively, waiting for researchers or scholars to explore and discover the truth. It is a construction needed by researcher or social groups they represent for the objective interests. In a sense, it is more of an ideology and has inevitable political and benefit.Since the 20th century, Aristotle's "view of essence" suffered more and more questions and challenges in the West. Western anti-essentialism is opposed to Aristotle's view of nature. And this kind of anti-essentialism is linked with the western anti-metaphysics, namely anti-traditional essence.
Under the influence of western anti-essentialism, the core problem of literary research, namely the essence of literature, is also questioned.

\section{The OUtDated Place OF ESSENTIALISM IN SOCIETY}

With the change and development of society and times, more and more researchers are beginning to change their understanding and perception of the essence of literature. They begin to gradually realize that the essence of literature has a lot of outdated places in society. First, Essentialism more and more didn't change. This forms a rigid production model which is closed, arbitrary and old. In ontology, essentialism doesn't assume that things have a certain essence but rather assume that things have a trans-historical, universal eternal essence which doesn't change due to the changes of space-time conditions; In epistemology, essentialism thinks that as long as subjects grasp the common cognitive methods, they can get trans-historical and absolutely correct understanding of essence and create universal and effective knowledge. Second, Essentialism is often accompanied by some form of coercion which imposes conditions arising in a particular situation under general circumstances. For example, certain specific groups produce the understanding of the literary features for specific purpose or interest, or make the knowledge of literature in dominant position on a certain period of time generalized as the "general essence" or "eternal essence" of literature. If supported by academic and non-academic powers outside of literature, it will be hegemonic knowledge and imposed on other social groups. Third, since essentialism often attributes the particular literary and literary features appearing in a specific space-time context to universality or typicality, sometimes there will inevitably be the phenomenon of partial generalization or over-generalization. Because the literature exists more or less differences in a different time and space environment or the same time and space environment, this kind of situation ignores the diversity of literature. It is absurd using a uniform standard to measure differences within literature.

\section{A SURVEY OF ANTI-ESSENTIALISM 'S IMPACT AND TURN ON ESSENTIALISM}

From the end of the 19th century, the western philosophical circles set off a huge current of "anti- 
metaphysics" which is substantially the doctrine of antitraditional essence. Because Hegelian philosophy is the master of western traditional essentialism philosophy, it became the main object attacked by the various schools of modern western philosophy. The current of "Antimetaphysics" even influenced and run through the development and trend of the 20th century's Western philosophy. Marxism, scientific positivism, irrationalism, existentialism and de-constructivism in the twentieth century and other modern genre all attacked and criticized traditional essentialism from different standpoints and for different purposes. Essentialism has suffered a comprehensive hit and "rejection". The criticism for the traditional metaphysical essentialism by modern theory announced the end of the essentialist concept which pursuing the essence of the eternal entity and the transcendental essence, laying the knowledge base as the main task, and achieving the absolute truth as the ultimate concern.As far as literary essentialism is concerned, the western traditional literature research pattern has undergone a great change after influenced by "antimetaphysics". The research model of Western traditional poetics, which has been dominated by essentialism for over two thousand years, is completed broken. In addition, the research model of literary essentialism has suffered a great impact and the research idea of substantialism is questioned. Now People have turned to the perspective of relationship to study the problem. Many schools of thought turn to research literature from the phenomena and the world of life and literature research field appears the trend of returning to the world of life. Literature research no longer makes pursuing to grasp the nature of the entity behind as purpose, but pays more attention to the complex relationship between literature and real life world. Therefore, it can be seen that the doctrine of essentialism has suffered a serious blow.

\section{THE COMMON FEATURES OF THE Following SIX RESEARCH MODELS ARE THE THINKING PATTERNS AND RESEARCH METHODS OF ANTI-ESSENTIALIST}

\section{A. The Impact of Marxism on Essentialism}

The Critique of Political Economy (Preface) points out that Marx regards literature art same as law, religion, politics and philosophy all belonging to "ideological forms" in the social structure ${ }^{1}$. They are all the reflection of social life and the reasons for their changes must be found in the change of socio-economic basis. This view is clearly an extension of the nature of anti-essentialist of Marxist philosophy in literary studies. This is another contribution for literary thought by Marx and Engels, that is, the reveal for the cognition and ideology of literature. This is also recognized by western scholars. René Wellek once commented: "Marxism as a method of revealing the potential social and ideological meanings is the most able to show its advantages." 2 The ideology of literature in the history of human thought for the first time in the social structure, rather

\footnotetext{
${ }^{1}$ Marx: "Critique of Political Economy" (Preface), see "The Complete Works of Marx and Engels" [M], the second volume;

${ }^{2}$ Wellek: "The Main Trends of Literary Criticism in the 20th Century",

"The Concept of Criticism", p. 330;
}

than in the coordinate system of ideology really establish the position of literature. This is also the best illustration of the characteristics of Marx opposing idealism and metaphysical essentialism.

\section{B. The Impact of Scientific Positivism on Essentialism}

Scientific positivism is another trend rising in the late 19th century of opposing western traditional metaphysics and criticizing essentialism. Its purpose is to transform and transcend traditional metaphysics in the spirit of empirical natural science and establish scientific ideology and the absolute authority of science. In addition, it had great influenced on the social development and western academic mechanism of the 19th century and the 20th century. The academic process of modern academic mechanism is mainly due to the influence of scientific positivism. It has greatly expanded the space and field of literature research, and promoted the study of literature to be more specialized, academic and systematic.

\section{The Impact of Irrationalism on Literary Essentialism}

After Kant made a critical and systematic critique of the traditional essentialism theory, in addition to Hegel still trying to overcome the shortcomings of traditional essentialism and establish a grand and complete rational essentialism, the development of metaphysics and essentialism also appeared in another direction, that is, the direction of emotional development. In the Romantic Movement, some people set the beauty as an eternal and transcendent fact and push it to the status of essence, which is actually an aesthetic perceptual essentialism doctrine. At the end of the 19th century, apart from the idea of aestheticism and French symbolism inheriting and developing romanticism, Germany and France appeared Schopenhauer and Nietzsche's voluntarism essentialism philosophy and Bergson's essentialist philosophy of life. They pushed the will and life to the position of essentialism. This genre is consistent with the position of other schools in the West. They all deny and criticize the traditional doctrine of rational essentialism. But they don't deny the existence of essentialism and metaphysics. They re-established new metaphysical existence in their own theory, affirmed the new view of existence must contain irrational elements and components, and highlighted the opposite of rational essentialism. The absolute value of perceptual essentialism forces the transformation of traditional rational essentialism theory. The emotional essentialism theory of the 19th century more prominent the absolutely important status of emotional and will. So they all used the path of irrationalism against traditional metaphysics.

\section{The Impact of Existentialism on Essentialism}

Existentialism is an influential school of modern philosophy in the West at the beginning of the 20th century. We take Heidegger's theory as an example. Heidegger criticized the traditional essentialism theory only by seizing the "being". He pointed out a fundamental error committed by traditional metaphysical essentialism since Plato. That is confusing the distinction between "Sein" and "Dasein". That 
is to say, the traditional essentialist doctrines affirm the existence of Dasein without knowing how it "exists" and make it as a fact not required to be questioned. Sein is understood according to the Dasein, and ultimately the "Sein" itself is understood as some "Dasein" - albeit it is the highest and most superior "Dasein". In this way, the traditional essentialism only seized the "Dasein" but forgot the "Sein", which replaced the study of the Dasein itself with the study of the Dasein. Actually, the two are fundamentally different. Therefore, the fundamental problem of Heidegger's philosophy is the ontological problem centered on the study of "in". He rejected the western traditional ontology since Plato and disagreed the positivist philosophers who rejected the ontology overall .He admitted that he is an ontological philosopher. The task proposed by himself is to destroy the past ontology and build a new ontology using phenomenological methods, the so-called basic ontology. This is also an impact on essentialism.

\section{E. The Impact of Deconstruction on Essentialism}

Deconstructionism rising in the sixties and seventies of the 20th century is an extremely influential philosophical social thought in the West. That is, the trend of postmodernism and linguistic trends triggered by the linguistic turn of the 20th century. It was put forward by the French philosopher Derrida. Derrida's analysis and criticism for the traditional theory of essence and metaphysics is more acute and profound. Its uniqueness lies in deep into the language structure and use postmodern subversive thinking patterns from the deep level to analyze and criticize the traditional metaphysical point of view. This has caused great impact on the literary essentialism. The pattern of the study of traditional literature and the core issues the study of literary theory have been completely subverted. Derrida believes that the traditional metaphysics has two pronouns: "Logos doctrine" and "presence of metaphysics". Derrida is by opposing the above two points of view to criticize essentialism. Imitation and reappearance are both the oldest literary concepts and is an important achievement of traditional literary essentialism. Derrida utterly denied the reappearance connection of the word and the external, and fundamentally criticized and negated the concept of the imitations and reappearance of literature, which thus formed a challenge and impact to the study of literary essentialism.

\section{F. The Impact of Cultural Studies on Essentialism}

Since the eighties of the 20th century, western academic circles have appeared a kind of ideological trend called cultural studies. Its theory source is French poststructuralism and the Birmingham culture school in the 1960s. It abandoned the pursuit and grasp the abstract natures behind reality things and emphasized to return the real life level, which put forward great challenges on the traditional cultural studies. And the evaluation of it is mixed. "Cultural studies" is as a new social science and humanities research method. Its spiritual essence is against essentialism and to form a strong challenge and impact to the study of essentialism. The prescriptions of cultural studies are "expansion" and "transcendence" to deny literary essentialism.

\section{THE REALISTIC UNDERSTANDING OF ESSENTIALISM AND ANTI-ESSENTIALISM}

Literary theory should be open. There isn't immutable truth in the world and no any law or essential feature which can be applied to all things. On the one hand, as with other cultural phenomena in human society, literature changes with the change of society. And there is no eternal essence. Things are all moving in the path of change and development However in the other hand, it can't be denied that literature has relative stability in a certain period of time. Therefore, in essentialism and anti-essentialism, the absolute change and relative stability is a pair of concomitant phenomenon.

\section{CONCLUSION}

Therefore, with the development of human society and literature, anti-essentialism also began to develop in philosophy in the late 20th century. In the field of literary theory, the understanding of the problem of the literature essence has also appeared the tendency of anti-essentialism. This negative is the view of the necessity and possibility of defining the essence of literature and is also a special view of essence. In fact, even those who hold this view can't deny that there is indeed a certain kind of common phenomenon of coherence and continuity between the different literary ideas and also can't deny people in a different time and space there have some degree of consensus for literary phenomenon. Literature is literature because there is always a certain objective, relatively stable, and continued existence of the basic nature and characteristics. And this consensus is the usual sense of the so-called nature and law. It is wrong view to blindly absolutize and solidify its consensus. But denying this consensus and negating the study of the commonality and continuity of the nature and characteristics of literature are also undesirable. We should regard literature as a multi-level and multi-faceted integrated system.

\section{REFERENCES}

[1] Wellek: "The Main Trends of Literary Criticism in the 20th Century", "The Concept of Criticism", p. 330.

[2] Marx: "Critique of Political Economy" (Preface), see "The Complete Works of Marx and Engels" [M], the second volume.

[3] Zhang Yu: "the nature of literature theory" [M]. Shanghai Sanlian Bookstore.

[4] Chen Chuan-cai: "the nature of the art of new theory" [M]. Renmin University of China Press.

[5] Hu Youqing: "literature study" [M]. Nanjing University Press.

[6] Tao Dongfeng Wang Nan: "the basic problem of literary theory" (third edition) [M]. Peking University Press.

[7] Tao Dongfeng: "Literary Theory: Constructive or essentialism - A branch and Yu, Ng Yuen, Mr. Zhang Xuchun" [J] Literary Contention, 2009.

[8] Wang Yuanxiang: "literary theory of the status quo and the future of my view" [J]. Shantou University, 2004.

[9] Zhi Yu: "anti-essentialism" literary theory is possible? - A Review of the New Discourse of Literature and Art "[J]. Theory of Literature and Art, 2006.

[10] Nan Fan: "Literary Studies: Essentialism, or Relationalism" [J]. "Literature and Art", 2007. 
[11] Cao Shunqing Wen Binbin: "The Essence of Pluralistic Literature Reflections on the Controversy between Essentialism and Constructivism" [J]. "Literary Contention", 2010.

[12] Zhang Hui: "anti-essentialist thinking and literary theory of production" [J]. "Literary Review", 2007.

[13] Wan Shui: "Recent years literature on" essentialism "and" constructivism "discussion" [J]. "Art", 2009.

[14] Yang Xingyu: "Literature Research essentialism question" [J] "Jishou University", 2010.

[15] Yan Ting: "Reflection" anti-essentialism ": from Literary Theory to Cultural Studies". [J] "Beijing University of Chemical Technology," 2011.

[16] Tang Tiehui: "Anti-essentialism" paradox and hegemony "[J]." Yangtze River Academic ", 2006.

[17] Fan Yongkang: "Literature emotional ontological foundation of muscle mass - anti-essentialism Literary Concept Review and Reflection" [J] "Guangxi Social Sciences", 2009.

[18] Li Tao: "" post-essentialism "literature and art is really possible? "Anti - essentialism" criticism of literary criticism "[J]." Oriental Series ", 2007. 